\title{
A DYNAMIC GENERAL EQUILIBRIUM ANALYSIS OF MIGRATION AND CAPITAL FORMATION: \\ THE CASE OF CANADA
}

Stuart J. Wilson

Department of Economics

University of Regina

Regina, Saskatchewan

Canada S4S 0A2

econ@uregina.ca

NOVEMBER 2000 


\title{
A Dynamic General Equilibrium Analysis of Migration and Capital Formation: The
}

\section{Case of Canada}

\author{
Stuart J. Wilson* \\ Department of Economics \\ University of Regina \\ Regina, Saskatchewan, Canada S4S 0A2
}

November 7, 2000

Suggested Running Head: Migration and Capital Formation

Contact:

Stuart J. Wilson

Department of Economics

University of Regina

Regina, SK, S4S 0A2

Tel: (306) 337-2230

Fax: (306) 585-4815

Email: stuart.wilson@uregina.ca

\footnotetext{
* The author would like to thank Alan Green, Allen Head, R.M. McInnis, and seminar participants at Queen's University, at the 2000 Meetings of the Society for Economic Dynamics, at the 2000 Meetings of the Canadian Economics Association, and at the Fourth World Congress of Cliometrics, for helpful comments and discussions. None other than the author can be held accountable for errors or oversights.
} 


\begin{abstract}
A dynamic general equilibrium model is constructed to examine the impact of mass immigration on capital accumulation in life-cycle economies. The model economies are populated by agents of overlapping generations with limited lifetimes, and are subjected to a series of migration shocks. The model is calibrated to match Canadian demographic characteristics over 1861-1913. The calibrated model is then used to examine the impact of this demographic shift on domestic savings and foreign capital inflow rates. Model results suggest that up to three-quarters of the increase in the capital formation rate and the foreign capital inflow rate, and all of the increase in the domestic savings rate, in the Canadian economy over 1899-1911, can be attributed to the dramatic inflow of migrants over this period.
\end{abstract}

Key words: migration; capital formation; saving; life cycle. 


\section{Introduction}

This paper presents a dynamic general equilibrium model to explain how migration affects capital accumulation in life-cycle economies. The model abstracts from business cycles, and earnings and employment uncertainty to isolate the impact of migration on the savings rate in a deterministic environment. The model is calibrated to match Canadian demographic characteristics over 1861-1913. To do so, I identify age and gender-specific Canadian net migration patterns over 1861-1911. During this period, Canada shifted from being a country of net emigration, to one of net immigration, circa 1897, with improved economic conditions leading up to the First World War. I then use the model to examine the impact of this demographic shift on domestic savings and foreign capital inflow rates. Model results suggest that up to three-quarters of the increase in the capital formation rate and the foreign capital inflow rate, and all of the increase in the domestic savings rate, in the Canadian economy over 1899-1911, can be attributed to the dramatic inflow of migrants over this period.

Canada's experience during the four decades leading up to WWI consisted of two remarkably different periods, with 1897 as the defining year of change. In the three decades following Confederation in 1867, Canada was a net supplier of migrants with emigration rates similar to those of Norway and the British Isles (McInnis (1994), and Hatton and Williamson (1994)). During this period, total real income growth averaged three percent per year, and capital formation rates amounted to about fifteen percent of real GNP (Urquhart (1988)). After 1896, the Canadian economy was dramatically

altered. Canada became a net receiver of immigrants with a net immigration rate of $15.1 \%$ over 1901 1911 (as a percentage of the 1901 population). Canadian real output grew six percent per year. Gross capital formation as a percentage of output grew steadily from twelve percent in 1896 to thirty three percent in 1913 (Urquhart (1988)). Figure 1 presents the Canadian gross domestic capital formation, 
domestic savings, and foreign capital inflows rates over 1870-1913. Figure 2 shows the annual pattern of migration for Canada from 1891-1913.

Econometric analysis has concluded that the increase in investment in Canada during this period was the result of increases in the population, and innovations to exports (Green and Sparks (1999)). The rise in the domestic savings rate was due in part to the dramatic increase in the working-age population (McLean (1994), and Wilson (2000)). However, Canada, with a young population, still required foreign capital inflows to meet the increased capital requirements during this period (Taylor and Williamson (1994)). Labor force growth raised capital requirements and pulled capital from foreign sources, "although what role labor force growth played in accounting for the massive capital flows to the New World remains an open question" (Taylor and Williamson (1994: 351)). This level of capital accumulation has not been repeated in Canadian history, nor has the rate of immigration. What impact did migration have on capital accumulation? New immigrants would have to be equipped for production, and social infrastructure would need to be developed. Can the massive inflow of immigrants account for the surge in capital accumulation that Canada experienced prior to WWI? Can the age-composition of immigrants explain the composition of investment between domestic and foreign sources?

The economic effects of immigration have garnered much attention in the US recently. Work has focused on the impact of immigration on wages and the migration of natives in response to immigration (see Borjas (1994), Friedberg and Hunt (1995), Filer (1992), and Card(1997)), and on the fiscal impact of immigration (Auerbach and Oreopoulos (1999), and Storesletten (2000)). The massive reallocation of labor that occurred during the age of mass migration, 1820-1913, has also been studied at length. Elaborate computable general equilibrium models have been developed to assess the impact of the massive reallocation of labor on real wages in Ireland (Boyer, Hatton and O'Rourke (1994)), on wage differentials between Britain and the United States (O'Rourke, Williamson and Hatton (1994)), 
and on growth and structural change in Argentina (Taylor (1997)). These static CGE models are useful in examining counterfactual assumptions of an economy at a point in time. Econometric models have been used to assess the role of migration on real wages in Australia and Canada (Pope and Withers (1994), and Green(1994)), economic growth in Canada (Green and Sparks (1999)), and growth and inequality in the Atlantic economy (Williamson (1998)). Long-run demographic change and its' influence on domestic savings rates and foreign capital flows in the US, Australia and Canada has also been modeled (McLean (1994), Taylor and Williamson (1994), and Wilson (2000)). Using time series data, these studies examine dynamic transitions of economies over time.

Dynamic general equilibrium models have been recently developed and used to model the impact of demographic change on an economy. The effect of an aging population on social security (Auerbach, Kotlikoff, Hagemann and Nicoletti (1989)), and on capital accumulation (Rios-Rull (1994)) has been modeled in a dynamic framework, as has the role of immigration policy and its' impact on fiscal policy (Storesletten (2000)). Canada provides an enticing case study in the role of demographic change in an economy at the beginning of the twentieth century.

This paper presents a dynamic (overlapping generations) general equilibrium model that examines the impact of immigration on life-cycle economies. The model combines elements used by Huggett (1996), where agents receive intergenerational transfers from accidental bequests, and Storesletten (2000), that accounts for age-specific migration. The model is calibrated to the Canadian economic environment in the years leading up to the Great War. Using census statistics of population, and estimates of survival rates, fertility rates, and immigrant flow data, the population process for Canada is recreated for the 1861-1913 period. The purpose of this paper is to isolate the effect of a migration transition, holding technological progress constant, and examine the implications of this change on capital accumulation. 
The contribution of this paper to the existing literature is in identifying age and gender-specific Canadian net migration patterns during the period of study, and in providing a preliminary answer to the open question of Taylor and Williamson (1994: 351). Results suggest that up to three-quarters of the increase in the capital formation rate and the foreign capital inflow rate, and all of the increase in the domestic savings rate, in the Canadian economy over 1899-1911, can be attributed to the dramatic inflow of migrants over this period.

Section 2 presents the dynamic general equilibrium model and the solution methodology. Section 3 discusses the calibration procedure, and section 4 presents the key modeling results. Section 5 concludes with directions for future research.

\section{An Overlapping Generations Model}

\subsection{The Environment}

The economy to be examined consists of overlapping generations of agents, following Auerbach and Kotlikoff (1987), Huggett (1996) and others, who live up to a maximum of I periods. Agents are heterogeneous in age and sex, and agent type is described by the subscript $i, h$ where $i$ denotes age and $h$ denotes gender. The age discrimination is made as agents in the model economy save for life-cycle reasons, and asset holdings will vary according to age. Agents are discriminated by sex in this model to account for age and gender-specific migration patterns, the labor force participation of young females, and allow for age-specific fertility rates for females. The framework does not model household formation but models independent agents.

The age distribution of the population at a point in time is denoted by the $(2 I \times 1)$ vector $\mu_{\mathrm{t}}$, where $\mu=\left[\mu_{1, \mathrm{f}} \mu_{2, \mathrm{f}} \ldots \mu_{\mathrm{I}, \mathrm{f}} \mu_{1, \mathrm{~m}} \mu_{2, \mathrm{~m}} \ldots \mu_{\mathrm{I}, \mathrm{m}}\right]^{\mathrm{T}}$. Agents of age $i$ and gender $h$ face a probability $s_{\mathrm{i}, \mathrm{h}}$ of 
surviving from the age of $i$ to the age of $i+1$ that is constant over time. The unconditional probability of surviving to age $k$ is $s(k)=\Pi_{j=1}^{k-1} s_{j}$. The vector of age and gender specific fertility rates is $\phi$, and is assumed constant over time. The number of newborns at time $t$ is:

$$
\mu_{1, k, t}=\sum_{i, h} \phi_{i, h}^{k} \mu_{i, h, t-1}
$$

where $k$ denotes the gender of the newborn, and $h$ denotes the gender of the agent (birth-parent).

The migration process to be described is adapted from Storesletten (2000) to suit the Canadian environment. Each year, immigrants enter the economy, also heterogeneous by age and gender. Immigrants enter the economy with the same skill and asset endowments as the existing population their own age. ${ }^{1}$ The number of immigrants of age $i$ and gender $h$ in each age category is set to a fixed proportion $\theta_{\mathrm{i}-1, \mathrm{~h}}$ of the survivors of age $i-1$ to age $i$. The population of age $i$ agents (where $i>1$ ) at time $t$ is:

$$
\mu_{\mathrm{i}, \mathrm{h}, \mathrm{t}}=s_{\mathrm{i}-1, \mathrm{~h}}\left(1+\theta_{\mathrm{i}-1, \mathrm{~h}}\right) \mu_{\mathrm{i}-1, \mathrm{~h}, \mathrm{t}-1}
$$

The law of motion of the population is represented by the matrix $\Gamma$, where, $\Gamma=$

$$
\left[\begin{array}{ccccccccc}
\phi^{f}{ }_{1, f} & \phi^{f}{ }_{2, f} & \ldots & \phi^{f}{ }_{I-1, f} & \phi^{f}{ }_{I, f} & \phi^{f}{ }_{1, m} & \ldots & \phi^{f}{ }_{I-1, m} & \phi^{f}{ }_{I, m} \\
s_{1, f}\left(1+\theta_{1, f}\right) & 0 & \ldots & 0 & 0 & 0 & \ldots & 0 & 0 \\
0 & s_{2, f}\left(1+\theta_{2, f}\right) & \ldots & 0 & 0 & 0 & \ldots & 0 & 0 \\
\ldots & \ldots & \ldots & \ldots & \ldots & \ldots & \ldots & \ldots & \ldots \\
0 & 0 & \ldots & s_{I-1, f}\left(1+\theta_{I-1, f}\right) & 0 & 0 & \ldots & 0 & 0 \\
\phi^{m}{ }_{1, f} & \phi^{m}{ }_{2, f} & \ldots & \phi^{m}{ }_{I-1, f} & \phi^{m}{ }_{I, f} & \phi^{m}{ }_{1, m} & \ldots & \phi^{m}{ }_{I-1, m} & \phi^{m}{ }_{I, m} \\
0 & 0 & \ldots & 0 & 0 & s_{1, m}\left(1+\theta_{1, m}\right) & \ldots & 0 & 0 \\
\ldots & \ldots & \ldots & \ldots & \ldots & \ldots & \ldots & \ldots & \ldots \\
0 & 0 & \ldots & 0 & 0 & 0 & \ldots & s_{I-1, m}\left(1+\theta_{I-1, m}\right) & 0
\end{array}\right]
$$

so that $\mu_{\mathrm{t}}=\Gamma \mu_{\mathrm{t}-1}$. Emigration can be modeled in a similar fashion, with immigration rates set to negative values (i.e. $\theta<0)$.

Agents maximize utility over a standard composite good, with time separable preferences and discount factor $\beta$. The composite good can also be used as capital, earning a risk-free one period return 
per unit, $R$, while the rate of return is $r=R-1$. The return is exogenously set on international markets. Agents are endowed with age and gender-dependent efficiency units of labor $e_{\mathrm{i}, \mathrm{h}}$, which they supply inelastically beginning at age $I_{\mathrm{w}}$ until retirement at age $I_{\mathrm{r}}$. Agents under the age of $I_{\mathrm{w}}$ do not work, do not consume, and do not make any decisions. Agents' preferences are summarized by the following utility function:

$$
E_{I_{w}}\left(\sum_{j=0}^{I-I_{w}} \beta^{j} s\left(j+I_{w}\right) U\left(c_{j+I_{w}}\right)\right), \quad \text { where } U(c)=\frac{c^{1-\sigma}}{1-\sigma}
$$

Production is deterministic and is governed by a constant returns to scale technology of the following form:

$$
Y_{t}=F\left(K_{t}, L_{t}\right)=A_{t} K_{t}^{\alpha} L_{t}^{1-\alpha}
$$

In order to isolate the impact of a change in migration patterns on the economy, technological progress, $A_{t}$, grows at a constant rate $g$, and capital depreciates at a constant rate $\delta$. The economy is a small open economy, so that the rate of return on capital is exogenously fixed to the international rate. Labor movements are taken as exogenous in the model. Capital can freely flow in and out of the economy. There is no role for government in the model economy. ${ }^{2}$

In period $t$, an agent chooses consumption, $c_{\mathrm{i}, \mathrm{h}, \mathrm{t}}$, and asset holdings, $a_{\mathrm{i}+1, \mathrm{~h}, \mathrm{t}+1}$, with the following budget constraint:

$$
c_{i, h, t}+a_{i+1, h, t+1} \leq W_{t}=R_{t} a_{i, h, t}+\omega_{t} e_{i, h}+T_{t} .
$$

In this context, $W$ denotes wealth, and $T$ is a lump-sum transfer. Individuals receive wage rate $\omega$ per efficient unit of labor. Agents are liquidity constrained such that they cannot have negative net asset holdings at any age. The value of $T_{\mathrm{t}}$ is determined by the amount of accidental bequests left by those who die in period $t$, before the age of $I$. The value of these bequests is then distributed amongst the adult population (those of age $I_{\mathrm{w}}$ or older). ${ }^{3}$ 
Agents make their decisions on asset holdings for period $t+1$ at time $t$ and cannot liquidate their holdings until time $t+1$. Immigrants at time $t$ enter the economy with foreign asset holdings, and their asset holdings at time $t+1$ are then considered to be held domestically. Emigrants at time $t$ do not work domestically at time $t$, however, their asset holdings are productive in the domestic economy at time $t$. Assets of emigrants are considered foreign at time $t+1$.

\subsection{Equilibrium Path}

A massive inflow of working age immigrants can drastically change the age distribution of the population. Not only do those of working age save, thus increasing domestic savings, but may require foreign capital flows to equip them for production. In order to compute a transition, initial and terminal conditions must be determined. As such, the transition will occur between two steady-state equilibria. The initial steady-state will involve a net emigration population process, and the terminal steady-state will involve a net immigration process. The steady-state age distributions of the population, $\mu_{\mathrm{ss} 1}$ and $\mu_{\mathrm{ss} 2}$, the new law of motion for population describing the transition to the second steady-state, $\Gamma_{\mathrm{ss} 2}$, and the open economy environment are taken as given. ${ }^{4}$

Transitional equilibria are defined recursively. At a point in time, the population distribution in the economy is defined by the vector $\mu_{t}$. The economy is also characterized by asset holdings of agents in each age and gender group, denoted by the vector $a_{t}$, and given the open economy environment, by the international risk-free return, $R_{t}$. The state of the economy is defined by $(\mu, a, R)$. The individual agent's state is $\left(e_{i}, R, a_{i}\right)$, where $a_{i}$ denotes the individual's own holdings of assets.

The agent's dynamic programming problem is now described. An agent's individual state is denoted by $(x, a)$, where $x=(e, R)$. The functions for consumption, $c(x, i, h, a)$ and next period's asset holdings, $a^{\prime}(x, i, h, a)$ are optimal decision rules that solve the following dynamic programming problem, given that in period $I+1$, the agent's value function is set to zero $(V(x, I+1, h, a)=0)$ : 


$$
V(x, i, h, a)=\max _{\left(c, a^{\prime}\right)} u(c)+\beta s_{i, h} E\left(V\left(x^{\prime}, i+1, h, a^{\prime}\right) \mid x\right)
$$

subject to

$$
\begin{aligned}
& \text { (1) } c+a^{\prime} \leq R a+\omega e(i, h)+T \\
& \text { (2) } c \geq 0 \text {, and } a^{\prime} \geq 0 \text { for all } i \text {. }
\end{aligned}
$$

Agents are liquidity constrained such that they cannot have negative net asset holdings at any age. The economy to be modeled is a small open economy, where the rate of return to capital is set exogenously on international markets, and capital can freely flow in and out of the economy.

Definition: A recursive open economy competitive equilibrium is a set of value functions, $V(x, i, h, a, t)$, a set of policy functions for asset holdings, $a^{\prime}(x, i, h, a, t)$, a set of policy functions for consumption, $c(x, i, h, a, t)$, and laws of motion for the population, aggregate capital stock, aggregate labor input, domestic capital, foreign capital, transfers, and functions for prices, $\left(\Gamma(t), K(x, t), L(x, t), K_{\mathrm{d}}(x, t), K_{\mathrm{f}}(x, t)\right.$, $T(x, t), \omega(x, t), R(x, t))$, such that:

(1) $c(x, i, h, a, t), a^{\prime}(x, i, h, a, t)$ are optimal decision rules that satisfy the agent's dynamic programming problem (equation (7) subject to (8) and (9));

(2) Input markets are competitive: $\omega(t)=F_{2}(K(t), L(t))$ and $R(t)=1+F_{1}(K(t), L(t))-\delta$, with $R$ set exogenously on international markets;

(3) The allocations are feasible:

(i) Domestic asset holding equal domestic capital, $K_{d}(t+1)=\Sigma_{i, h} \mu(i, h, t) a^{\prime}(x, i, h, a, t)$;

(ii) Foreign capital is the difference between total capital and domestic capital,

$$
K_{f}(t)=K(t)-K_{d}(t)
$$


(iii) Domestic wealth plus new immigrant wealth equals consumption and next period asset holdings, $\omega(x, t) L(x, t)+R(t) K_{\mathrm{d}}(x, t)+\sum_{\mathrm{i}, \mathrm{h}} \mu(x, i, h, t)(s(i, h) \phi(i, h)) a(x, i, h, t) R(x, t)=$ $\sum_{\mathrm{i}, \mathrm{h}} \mu(x, i, h, t) c(x, i, h, a, t)+\sum_{\mathrm{i}, \mathrm{h}} \mu(x, i, h, t) a^{\prime}(x, i, h, a, t)$

(4) Effective labor supply, $L(t)=\Sigma_{i, h} \mu(i, h, t) e(i, h)$;

(5) Transfers to the adult population equal accidental bequests, $T(t+1)=\Sigma_{i, h} \mu(i, h, t)(1-s(i, h)) R(t+1) a^{\prime}(x, i, h, a, t) / N_{a}(t+1)$, where $N_{a}$ denotes the number of adults in the population.

The method of computing the transition is adapted from Rios-Rull (1994, 1997). First, a sequence of population distributions is calculated using the population transition matrix with the first steady-state population distribution as the starting point. Next, a guess for the sequence of transfers is made. Given the sequence of transfers, the sequence of optimal asset holdings of agents in the economy can be computed recursively. Then, the values of accidental bequests (transfers) are calculated and compared to the guessed sequence of transfers. If the two sequences are equal the procedure is completed, otherwise, the guessed sequence of transfers is updated and the computational procedure is repeated until convergence is achieved. ${ }^{5}$

\section{Calibration}

Each period in the model economy corresponds to one year. Agents live up to a maximum of 95 years, begin supplying labor and making decisions at 15 years of age, and fully retire from the labor force at 90. ${ }^{6}$ There is no earnings or employment uncertainty in the model, and agents accumulate capital under the life-cycle motive. Agents do face uncertain lifespan, but agents commonly know age and genderspecific mortality rates. 


\subsection{Population}

The population process for Canada was calibrated using estimates of the population at census dates, estimates of fertility rates, crude birth rates, mortality rates, and immigrant flow statistics. The census population figures are taken from Urquhart and Buckley (1965), and are gender specific in five-year age cohort groupings with the exception of the elderly (i.e. the groupings are: under 5, 5-9, 10-14, .., 65-69, and 70 and older). Survival rates were derived from the mortality estimates of Bourbeau and Legare (1982) at census years (i.e. 1871, 1881, etc.), and are also gender-specific in five-year age cohort groupings, with the exception of infants (under one year, and 1-5 age groups). The mortality estimates imply that all agents die before 96 years of age. In the calibrated model, no agent survives past his or her ninety-fifth birthday.

Fertility rates were constructed using the 1926 age-specific fertility rates of females from Urquhart and Buckley (1965) in five-year cohorts from 15-19 years of age, to 45-49 years of age. The age distribution of female fertility rates is not available for Canada prior to 1926, and as such, the age distribution of fertility rates is assumed fixed for the period of study to the 1926 distribution. These fertility rates were then scaled to match the crude birth rate estimates of McInnis (1999a, 1999b) for the years $1871,1881,1891,1901$, and 1911. The male-female split among newborns is set to $1.05: 1{ }^{7}$ Survival and fertility rates were assumed constant over all ages in each cohort group.

The estimates of the population during a census year were derived by solving the following equation in order to approximate the population within a cohort group $\left(\mu_{\mathrm{c}}\right)$ according to survival rates:

$$
\mu_{\mathrm{c}}=\mu_{\mathrm{i}}+\mu_{\mathrm{i}+1}+\mu_{\mathrm{i}+2}+\mu_{\mathrm{i}+3}+\mu_{\mathrm{i}+4}=\mu_{\mathrm{i}}+s_{\mathrm{i}} \mu_{\mathrm{i}}+s_{\mathrm{i}+1} s_{\mathrm{i}} \mu_{\mathrm{i}}+s_{\mathrm{i}+2} s_{\mathrm{i}+1} s_{\mathrm{i}} \mu_{\mathrm{i}}+s_{\mathrm{i}+3} s_{\mathrm{i}+2} s_{\mathrm{i}+1} s_{\mathrm{i}} \mu_{\mathrm{i}},
$$

so that,

$$
\mu_{\mathrm{i}}=\mu_{\mathrm{c}} /\left(1+s_{\mathrm{i}}+s_{\mathrm{i}+1} s_{\mathrm{i}}+s_{\mathrm{i}+2} s_{\mathrm{i}+1} s_{\mathrm{i}}+s_{\mathrm{i}+3} S_{\mathrm{i}+2} s_{\mathrm{i}+1} s_{\mathrm{i}}\right) .
$$


In certain cases ( $i=1$ being the most notable case), the estimate for $\mu_{\mathrm{i}+4}$ was lower than the estimate for $\mu_{\mathrm{i}+5}$, the first estimate of the subsequent cohort group. This appears to be an indication of underenumeration (Coale and Zelnik (1963)).

In order to derive estimates of emigration over the last half of the nineteenth century, a no net migration population process was first modeled over ten year intervals, between census dates for the 1861 to 1901 period. The process was calibrated with mortality, fertility and crude birth rate estimates at the end of the decade, and initial census population statistics for the decade. The resulting tenth year population under the natural increase scenario was then compared to the corresponding census statistics of age and gender-specific cohort groups. For example, the 1861 initial population distribution was used to model the population for the years 1862 to 1871 , then the 1871 results were compared to the actual 1871 census figures. Emigration was derived as a residual. Then, a rough estimate of average annual emigration rates was constructed by modeling the population process with both natural increase and emigration parameters until the estimates converged to the corresponding census figures. ${ }^{8}$ The estimated emigration rates were generally consistent over the 1861-71, 1871-81, 1881-91 and 18911901 census years for the working age population, and were used to generate the first steady-state population distribution $\mu_{\mathrm{ss} 1}$, and transition matrix $\Gamma_{\mathrm{ss} 1}$.

The emigration rates derived by using this methodology are presented in Figure 3. Some explanation of the rates is in order. The emigration rates for females of working age were higher than those of males. This arises because in 1871 and 1881, there were more working age females than males, and in 1891 and 1901, this was reversed as there were more working age males than females. Emigration was concentrated in the 20-39 age cohorts. ${ }^{9}$

Immigration rates were derived in a similar manner, but were set to be uniformly increasing over the 1902-1911 period to match the increasing number of immigrants over the decade. For example, average immigration rates for the intercensal period were scaled by $1 / 5$ for the first year, $2 / 5$ for the 
second and so on, until the rates for the tenth year were two times the average rates. The average rates were then adjusted by modeling the population from 1901 till 1911, under this scaling method, to correspond to the census figures of 1911. The resulting immigration rates for the year 1911 were then used to define the population transition matrix $\Gamma_{\mathrm{ss} 2}$. The rates used for the second steady-state are presented in Figure 4. The fertility and mortality rates were kept at the 1901 rates in constructing the population transition matrices, $\Gamma_{\mathrm{ss} 1}$ and $\Gamma_{\mathrm{ss} 2}$, for the model economy.

The composition of immigrants was skewed towards young working age males, who have the highest employment rates in the population. In 1901 there were 47 thousand more males than females between the ages of twenty and thirty-nine. In 1911, the corresponding figure rose to 269 thousand. The derived age-specific immigration rates also indicate high immigration among males aged 40 to 45 and females aged 35 to 40. This supports the evidence presented by Troper (1972). American families with adult children were selling their farms while land prices in the US were rising. They migrated to Canada, and bought a series of neighboring farms to provide for their grown and growing children. That way, families were able to stay close together. ${ }^{10}$

\subsection{Earnings and Employment}

The age-earnings profile is adapted from Green and McKinnon (1997). They found little difference between the earnings profile of immigrants and natives in Toronto in 1901, and found that the profile flattens out after about thirty years of age. Earnings of those over the age of 65 were set to ninety-four percent of wages earned by those between the ages of thirty and sixty-four. ${ }^{11}$ The age-earnings profile for females was set equal to half that of males. ${ }^{12}$ Age and gender-specific employment rates were set to the 1921 estimates in Urquhart and Buckley (1965). Employment rates for men over fifty-five years of age were adjusted using the estimates reported in Costa (1998) for US males in 1900, to allow for a 
general decline in the rates. ${ }^{13}$ Labor endowment is calculated as the product of age and gender-specific employment rates and earnings. These parameters are presented in Figure 5.

\subsection{Preferences and Technology}

The values of $\beta$ and $\sigma$ were set to 1.011 and 1.12, following the estimates established by Hurd (1989). The production function is a standard Cobb-Douglas with the share to capital, $\alpha$, set to 0.15 . The value used by Green (1999) is 0.21 for the twentieth century as a whole. An estimate of $\alpha$ from Urquhart and Buckley (1965), by dividing the sum of corporate profits before taxes, interest and other investment income, and capital cost allowances, by GNP, was 0.22 for 1926 and rises to 0.26 for 1960 . High values for $\alpha$ lead to high capital-output ratios. Values higher than 0.16 cause the replacement of depreciated capital to exceed ten percent of income. This would imply that more than just domestic savings in the 1870-1896 period were needed to maintain the capital stock. Higher values for $\alpha$ also lead to excessively large values for gross domestic capital formation. The parameter was set to 0.15 and generates a ratio of depreciated capital to output of $8 \%$. This is consistent with the Green and Urquhart (1976) estimates of depreciation of between eight and nine percent of output over 1870-1920. The value for $g$, technological progress, is set to 0.0185 . The average annual growth rate in real GNP per worker over 1901-1911 was 1.8\% (Urquhart (1988)), and the average rate of growth in real wages over 18701914 was $1.86 \%$ (Williamson (1998)).

The average capital cost allowance as a proportion of gross industry capital was about six percent between 1926 and 1949. Capital cost allowance also ranged from eight to twelve percent of output during this period (Urquhart and Buckley $(1965: 130,139)$ ). With a capital-output ratio of 3, this would amount to an allowance of three to four percent of capital. The two model economies have a depreciation rate of 0.032 with the return to capital set to $2.8 \%{ }^{14}$ The values for $R$ and $\delta$ are calibrated 
to provide reasonable gross domestic formation rates and current account balances, and to closely resemble the estimates made by Urquhart (1988) before the change in migration patterns.

\subsection{Transition}

The GE model was used to model the economy with the population now to be described. At time $t=1900$, the population distribution is set equal to the first steady-state distribution, $\mu_{\mathrm{ss} 1}$. For $t=1900-\mathrm{j}$, $\mathrm{j}>0$, the population is set to $\left(\Gamma_{\mathrm{ss} 1}\right)^{-\mathrm{j}} \mu_{\mathrm{ss} 1}$. At time $t=1901$, there is no net migration. Then, the immigration process grows as described above from $t=1902$ to $t=1911$. The rates for the 1912 and 1913 were calibrated to 1.1 times the rates for 1911 (to continue the general upward trend in migration from 1911 to 1912), and thereafter migration follows the process implied by $\Gamma_{\mathrm{ss} 2}$, corresponding to the second steady-state. The net migration figures from the model economy with this migration process, denoted Model Economy A, are compared to other migration estimates in Figure 6. A second model economy, denoted Model Economy B, has a migration transition where age and gender-specific migration rates during the transition period are scaled in order to match the overall net migration estimates of Firestone (1958) over 1901 to 1914 . For example, the age and gender-specific migration rates from Model Economy A, corresponding to the year 1902, were multiplied by a factor of 3.1 to generate the rates for Model Economy B to match the Firestone estimates of overall net migration rate for 1902 . So, the migration transition described by Model Economy A is a gradual one, with migration increasing over the period to correspond to the generally increasing pattern in the official gross immigration series over 1901-1913. The migration transition described by Model Economy B resembles that implied by the Firestone net migration series from 1901 to 1913.

This is not meant to imply that the Canadian economy was in a steady-state in the years leading up to 1901 , nor was the economy in a steady-state in 1911 or soon thereafter. However, in order to compute a migration transition, steady-states are needed as starting and ending points. ${ }^{15}$ The focus of 
this exercise is to model a migration transition similar to that for Canada over 1900-1911, and examine the impact of this change on capital accumulation.

\section{Results}

The dynamic model produces several series that will now be defined. Real national income is set equal to total labor income, $\omega L$, plus the return on domestically held capital, $(R-1) K_{\mathrm{d}}$ and will hereafter be simply referred to as national income. Gross domestic capital formation at time $t$ is equal to the increase in the capital stock from time $t$ to time $t+1$, plus depreciated capital. The capital formation rate is equal to gross domestic capital formation divided by national income. The domestic savings rate at time $t$ is defined as the increase in the stock of domestically held capital from time $t$ to time $t+1$, plus depreciated capital, all divided by national income at time $t$. The net foreign capital inflow rate at time $t$ is defined as the increase in foreign-held domestic capital (net of domestically-held foreign capital) from time $t$ to time $t+1$, divided by national income at time $t$.

\subsection{Steady-states}

First, a description of the steady-states defining the initial and terminal conditions of the computed transitions is in order. Table I provides a summary of the key model steady-state results. Given the parameters set above, the model economies have a capital-output ratio of 2.50 . The first steady-state is characterized by an annual population growth rate of $0.4 \%$. This is lower than the actual population growth rate of Canada over 1861-1901, due to the assumption of constant survival and fertility rates, set to the rates of 1901, and to the difficulties in calibrating to census data. The annual population growth rate in the second steady-state, corresponding to a population transition as described by $\Gamma_{\mathrm{ss} 2}$ is $3.5 \%$. 
The real income growth rate in the first steady-state is $2.3 \%$ per year, while the rate is $5.4 \%$ in the second steady-state. These rates are equal to the growth rate in the population plus the growth rate in per capita income, in this case, the rate of technological progress. The growth rate in per capita real income in both steady-states is $1.85 \%$.

The calculated rates of capital accumulation and domestic savings are gross rates, therefore include the replacement of depreciated capital. The ratio of capital accumulation to national income is $15.4 \%$ and $27.2 \%$ in the first and second steady-states. This rise is due to the increased annual net inflow of working age migrants in the second steady-state compared to the first. Capital requirements are increased to equip these migrants for production, and for housing and other social overhead needs.

The domestic savings rate in the first steady-state is $12.7 \%$ of national income, and $16.9 \%$ in the second steady-state. The increase in the domestic savings rate does not match that of the capital formation rate. Since migrants are primarily in the $20-45$ age group, the capital requirements to equip them for production and for the development of social infrastructure outweigh the supply from domestic sources. Domestic sources of investment funds cannot meet the increased investment requirements in the second steady-state, and so the net capital inflow rate rises from $2.7 \%$ in the first steady-state, to $10.3 \%$ in the second.

\subsection{Transitional Dynamics}

The economies were then modeled to generate the transition from the first steady-state equilibrium under the net emigration scenario, to the second steady-state under the net immigration scenario. The period of interest is the years of the transition in the model economies, corresponding to 1899 to 1911 for Canada. The start date of 1899 is chosen since the model economy transition begins in 1901 and capital requirements for production in 1901 must be planned in 1900. So, 1899 is the last period where formation rates are unchanged from the previous period in the model economies. The migration 
transition described by Model Economy A is a gradual transition, with migration increasing over the period to correspond to the generally increasing pattern in the official gross immigration series over 1901-1913. The migration transition described by Model Economy B resembles that implied by the Firestone (1958) net migration estimates over 1901-1913 (see Figure 6).

The massive inflow of working age immigrants in the open economy framework has the impact on key economic variables as depicted in Figure 7. The model results show that foreign capital inflows are more responsive to population movements than domestic savings. Immigrants were primarily young adults and young families, who generally hold little capital. Young workers do not hold enough capital to supply themselves in production, nor to fully provide for the development of social infrastructure. The gross domestic capital formation, domestic savings and foreign capital inflow rates generated by the model economies are compared to the actual Canadian rates in Figures 8, 9, and 10. The Canadian rates are smoothed by using three-year centered averages. This is done in order to reduce the stochastic yearto-year variation in the actual series and to better enable a comparison with the deterministic series generated by the model economies.

The upward trend in gross domestic capital formation rates of the model economies are similar to the trend exhibited in the actual series as shown in Figure 8, however, for Model Economy B, the rate of capital formation declines in 1907 and is much lower than the actual rate thereafter. This is the result of a fall in the net migration estimates of Firestone. The gross domestic capital formation rate in Canada increased by 0.16 over the $1899-1911$ period. The rate of the model economies increased by 0.12 and 0.06 for Economies A and B respectively over this decade. These results suggest that up to $79 \%$ of the increase in the gross domestic capital formation rate over 1899-1911 can be attributed to a gradual migration transition, but only $36 \%$ would be due to a migration transition implied by the Firestone estimates (see Table II). 
The Canadian domestic savings rate rose to $16 \%$ in 1911 . The general increase in the rate from 1899 to 1911 was 3.9 percentage points over the rate in 1899 . The rate generated by the model economies increased by 4.2 percentage points for Model Economy A, and 2.7 percentage points for Model Economy B from 1899 to 1911 . These results, also presented in Table II, suggest the migration transition in Canada can be responsible for between three-quarters and all of the total increase in the domestic savings rate during the period of study.

The Canadian foreign capital inflow rate is compared to that of the model economies in Figure 10. The actual rate increased by 12.3 percentage points during the period of study, while the rate for Model Economy A rose by 8.6 percentage points, and the rate for Model Economy B rose by only 3.1 percentage points. These results suggest a gradually increasing inflow of migrants can explain about three-quarters of the rise in the foreign capital inflow rate in Canada during the first decade of the twentieth century (see Table II). However, by accounting for the time pattern of migration implied by Firestone, only one-quarter of the rise in the rate can be attributed to the rise in net migration.

The results generated by model economies A and B are sensitive to the path of migration, however, both generate the same level of total capital stock at the end of the period in 1911 because the population is identical in 1911 in both cases. A comparison of the results from Model Economy B (using the time path of migration implied by Firestone) with the actual estimates suggests that foreign capital flows were delayed into Canada. When net migration tailed off after 1907, foreign capital continued to pour into the country consistent with the gross immigration flows in the latter half of the decade. By 1912, Canada was preparing for 400,000 immigrants in one year, an addition of 5\% to the population, and enough to calm fears at the time that too much foreign capital was entering Canada (Field (1914: 237-8)). The results for Model Economy B, however, suggest otherwise. Emigrant flows were not recorded at the time, as it was easy for people to cross the border between Canada and the US. While the Canadian economy was preparing for an increasing flow of immigrants, it was not preparing 
for a corresponding increase in the flow of emigrants. As such, the model results suggest foreign capital inflows were sensitive to the perception of continued increasing immigration without the expectation of increasing emigration.

The results of the model economies during the period of transition give us an indication of the relative amounts of immigrant wealth brought into the economy with respect to foreign capital inflows. In the open economy environment, the rise in the domestic savings rate is the result of immigrant wealth coming into the country and being held by new residents of the country. ${ }^{16}$ During the $1902-1914$ period, net immigrant receipts amounted to $\$ 252$ million. Cumulated net long-term foreign capital inflows for the period were $\$ 2.1$ billion (Urquhart (1993: Table 1.4)). The ratio of immigrant capital to net foreign capital inflows for the period is 0.12 . The corresponding ratio for Model Economy A is 0.21 , while that for Model Economy B is 0.19. The model economy ratios are higher because the model economies do not replicate the surge in foreign capital over 1910-1913. The ratio for Canada over 1902-1909 is 0.17, more consistent with the model economy results.

Canada experienced a dramatic fall in immigration with the outbreak of World War I. Are the results sensitive to the assumption of a continued high rate of immigration into Canada? The answer is no for the pre-war period. A model economy with migration rates set to zero after 1914 will exhibit a decline in the capital formation rate, domestic savings rate and the foreign capital inflow rate, but only after 1913. During the $1899-1913$ period, these rates vary no more than 0.1 percentage points from the scenario with a continued immigration process as defined by Model Economies A and B. The results during the study period are not sensitive to the assumptions of the second steady-state population process in the open economy environment, but to the transition environment itself.

These results must be treated with caution. The actual Canadian series exhibit stochastic patterns, while the series generated by the model economy are deterministic. This makes a comparison tentative. The model does not capture the surge in the domestic savings rate that occurred over 1897 - 
1902. This was a period of recovery for Canada, as it pulled out of a depression in the mid-1890s. As such, this surge may be reflecting a business cycle. The model does perform well in explaining the role of changing migration patterns and it's impact on the capital formation rate, the domestic savings rate, and the foreign capital inflow rate. The results confirm the findings of Green and Sparks (1999) that population innovations were a significant factor in shifting up the growth path of investment during the two decades prior to WWI. The New World with a younger population was reliant on the Old World for capital. The time pattern of increased foreign capital flows coincides closely with that of rising annual immigration. Since foreign investment in Canada was primarily in government and railroad securities and other population-sensitive investment, it appears that population growth was the primary force in pulling in foreign capital. ${ }^{17}$ This paper sheds light on the open question of how labor force growth, through immigration, can account for massive capital inflows in the destination country, while at the same time, account for an increasing domestic savings rate. In the open economy environment, the rise in the domestic savings rate is the result of wealth coming into the country with working-age immigrants, who are also net savers in the economy. The domestic savings rate does not change as a result of fundamental changes in the consumption-saving decision of individuals.

\section{Conclusion}

A dynamic general equilibrium model is constructed to examine the impact of mass immigration on capital accumulation. The model is calibrated to match Canadian demographic characteristics over 1861-1913. During this period, Canada shifted from being a country of net emigration, to one of net immigration, circa 1897, with the prospect of profitable farming in the Prairies and the development of a transcontinental economy. As a result of modeling the Canadian population process over 1861-1911, I identified age and gender-specific migration patterns. The results indicated that emigrants over 1861- 
1901 were predominantly individuals between the ages of 20 and 30, with net emigration rates of females higher than those of males. Results also indicated that immigration over 1901-1911 was predominantly concentrated among males aged 16 to 30 and 40 to 45 , and females aged 16 to 25 and 35 to 40 . Moreover, the rate of adult male net immigration was much higher than that of adult females. The calibrated model was then used to examine the impact of this shift in migration on the domestic savings rate, and the foreign capital inflow rate. Model results suggest that up to seventy-five percent of the rise in the capital formation rate, and up to all of the rise in the domestic savings rate, in Canada over 1899-1911, can be attributed to the dramatic inflow of migrants over this period. The results also suggest an answer to the open question put forth in Taylor and Williamson (1994): labor force growth, through immigration, appears responsible for up to three-quarters of the rise in the foreign capital inflow rate. The results confirm the findings of Green and Sparks (1999) that population innovations were a significant factor in shifting up the growth path of investment during the two decades prior to WWI. Model results have demonstrated how sensitive capital formation is to the time path of migration. It appears much of the dramatic rise in the gross domestic capital formation rate and the foreign capital inflow rate were the result of expectations of a continued upward trend in immigration. The Canadian economy was not expecting a corresponding upward trend in emigration.

This paper has demonstrated the ability of a calibrated dynamic equilibrium model to assess the impact of changing migration patterns on capital accumulation. The results suggest directions for further research. This study treats labor movement as exogenous, and capital as endogenous. Land and natural resources are treated as exogenous and are incorporated into $A$, the parameter describing technological progress in equation (5). A natural question is: what's exogenous? If one were to treat land and resources as exogenously given and capital and labor as endogenous, one would need to model both labor and capital movements as a result of resource "discovery" and model these implications on the returns to labor and capital. In this study, this endowment "discovery" is included in the growth rate 
of technological progress for Canada, given that output per worker increased by $1.8 \%$ per annum in the first decade of the twentieth century. ${ }^{18}$

The Canadian population experienced an immigration shock after both World Wars, along with a baby boom in the post-WWII period. The Canadian savings rate also surged following both wars, accompanied by increases in foreign capital inflows. A dynamic GE model can be constructed to examine the impact of these migration shocks on world economies. More recently, policymakers and economists have been concerned with the general decline in personal and aggregate savings rates in developed nations since the 1970s. During this time, social policies have become more widespread. Government pension and social security programs affect the life cycle savings motive of individuals, while unemployment insurance programs affect the precautionary savings motive. The model presented in this paper can be adapted to examine these institutional changes and their effect on capital accumulation.

\section{Appendix 1: Computation of Equilibria}

\section{A1.1. Solving for the Steady-state}

The variables are transformed as follows to remove the effects of growth in the population and of technology:

$$
\begin{gathered}
\tilde{L}_{t}=L_{t} / L_{t}, \tilde{K}_{t}=K_{t} / L_{t} A_{t}, \tilde{T}_{t}=T_{t} / A_{t}, \tilde{a}_{t}=a_{t} / A_{t}, \tilde{c}_{t}=c_{t} / A_{t}, \tilde{\omega}_{t}=\omega_{t} / A_{t}, \\
\tilde{\mu}_{t}=\mu_{t} / L_{t}, \tilde{N}_{t}=N_{t} / L_{t} .
\end{gathered}
$$

As such, an agent's dynamic programming problem may now be described. An agent's state is denoted by $x=(\tilde{a}, e, R)$, productive capital asset holdings, labor endowment and the international risk-free return. The functions for consumption $\tilde{c}(x, i, h)$ and asset holdings $\tilde{a}^{\prime}(x, i, h)$ are optimal decision rules 
that solve the following dynamic programming problem, given that in period $I+1$, the agent's value function is set to zero $(V(x, I+1)=0)$ :

$$
V(x, i, h)=\max _{\left(\tilde{c}, \tilde{a}^{\prime}\right)} u(\tilde{c})+\beta(1+g)^{1-\sigma} s_{i, h} E\left(V\left(x^{\prime}, i+1, h\right) \mid x\right)
$$

subject to

$$
\begin{aligned}
& \text { (1) } \tilde{c}+(1+g) \tilde{a}^{\prime} \leq R \tilde{a}+\omega e(i, h)+\tilde{T} \\
& \text { (2) } \tilde{c} \geq 0 \text {, and } \tilde{a}^{\prime} \geq 0 \text { for } i=I .
\end{aligned}
$$

The additional term $(1+g)^{1-\sigma}$ in the objective function appears due to the transformation of the variables to remove growth.

In the steady-state, the transformed variables for capital and labor inputs, for transfers and for the age-distribution of agents in the economy are constant over time. The untransformed variables therefore all grow at constant rates.

Definition: A steady-state open economy equilibrium is $\left(\tilde{c}(x, i, h), \tilde{a}^{\prime}(x, i, h), \tilde{\omega}, R, \tilde{K}, \tilde{L}, \tilde{T}\right)$ such that:

(1) $\tilde{c}(x, i, h), \tilde{a}^{\prime}(x, i, h)$ are optimal decision rules;

(2) Input markets are competitive: $\tilde{\omega}=F_{2}(\tilde{K}, \tilde{L})$ and $R=1+F_{1}(\tilde{K}, \tilde{L})-\delta$, with $R$ set on international markets, and here assumed constant;

(3) The allocations are feasible:

(i) Domestic asset holdings equal domestic capital $\widetilde{K}_{d}=\Sigma_{i, h} \tilde{\mu}(i, h) \tilde{a}(i, h) /(1+n)$;

(ii) Foreign capital is the difference between total capital and domestic capital:

$$
\widetilde{K}_{f}=\tilde{K}-\tilde{K}_{d}
$$


(iii) Domestic wealth plus new immigrant wealth equals consumption and next period domestic asset holdings:

$$
\widetilde{\omega} \tilde{L}+R \tilde{K}_{d}+\Sigma_{i, h} \tilde{\mu}(i, h)(s(i, h) \phi(i, h)) \tilde{a}(i, h) R=\Sigma_{i, h} \tilde{\mu}(i, h) \tilde{c}(i, h)+\Sigma_{i, h}(1+g) \tilde{\mu}(i, h) \tilde{a}^{\prime}(i, h)
$$

(4) Effective labor supply: $\tilde{L}=\Sigma_{i, h} \tilde{\mu}(i, h) e(i, h)=1$;

(5) Transfers to the adult population equal accidental bequests:

$\tilde{T}=\Sigma_{i, h} \tilde{\mu}(i, h)(1-s(i, h)) R \tilde{a}(i, h) / \tilde{N}_{a}(1+n)$, where $N_{a}$ denotes the number of adults in the steady-state population.

In order to compute the steady-state of the model economy, the steady-state age distribution of this economy must be derived. To do this, the eigenvalues and eigenvectors of the matrix describing the law of motion of the population are computed. The largest eigenvalue of the matrix $\Gamma$ is equal to the steady-state growth rate of the population. The steady-state age distribution of the population is defined by the product $\mu^{*}=\tilde{\Gamma}^{\mathrm{b}} \mu$, where each element of $\tilde{\Gamma}$ is equal to the corresponding element of $\Gamma$ scaled by its' largest eigenvalue, and where $b$ is sufficiently large so that $\tilde{\Gamma}^{\mathrm{b}+1} \mu-\tilde{\Gamma}^{\mathrm{b}} \mu \cong(0)$.

In the small open economy framework the return on capital is determined on international markets. Given the steady-state age distribution, the aggregate steady-state capital stock is calculated by solving the equation that defines the return on capital. Wages are set to the marginal productivity of labor. Steady-state equilibria are computed using the following algorithm:

(1) Guess the value for the transfer of accidental bequests, $\tilde{T}$.

(2) Calculate the optimal decision rules, $\tilde{c}(x, i, h), \tilde{a}^{\prime}(x, i, h)$, of agents aged $I_{\mathrm{w}}$ to $I$, with the values of $\tilde{a}_{I_{w}-1}$ and $\tilde{a}_{I+1}$ set to zero. These rules are achieved by recursively solving a series of 
second order difference equations, from the Euler equation of the optimization problem, of the following form:

$$
\begin{aligned}
& (1+g)^{-1 / \sigma}\left(R \tilde{a}_{i}+\tilde{T}+\tilde{\omega} e_{i}-(1+g) \tilde{a}_{i+1}\right) \\
& -\left(\beta R s_{i}(1+g)^{1-\sigma}\right)^{-1 / \sigma}\left(R \tilde{a}_{i+1}+\tilde{T}+\tilde{\omega} e_{i+1}-(1+g) \tilde{a}_{i+2}\right)=0
\end{aligned}
$$

(3) Calculate the value of $\tilde{T}$ implied by $\tilde{a}^{\prime}(x, i, h)$ from step (2).

(4) If the value of $\tilde{T}$ calculated in step (3) differs from the initial guess in step (1), repeat the procedure using the result from step (3) as the initial guess until convergence is achieved.

\section{A1.2. Computing the Transition}

The method of computing the transition is as follows:

(1) Compute the sequence of vectors $\left\{\mu_{t}\right\}_{t=t_{1}}^{b+t_{1}}$, given the calibrated population transition sequence and $\Gamma_{\mathrm{ss} 2}$, the law of motion of population that describes the second steady-state.

(2) Guess a sequence of transfers $\left\{T_{t}^{0}\right\}_{t=t_{1}}^{b+t_{1}}$, with $T_{t<t_{1}}=T_{s s 1}$, the level of transfers in the first steady-state, and $T_{t>b+t_{1}}=T_{s s 2}$, the level of transfers for the second steady-state.

(3) Solve for the vector of optimal asset holdings, sequence $\left\{a_{t}^{1}\right\}_{t=t_{1}}^{b+t_{1}}$, so that the Euler equations hold for all $i, h$, and $t$.

(4) Compute the imputed sequence of transfers $\left\{T_{t}^{1}\right\}_{t=t_{1}}^{b+t_{1}}$, where $T_{t}^{1}=\Sigma_{i, h} \mu_{i, h, t-1}\left(1-s_{i, h}\right) R_{t} a_{i, h, t-1} / N_{t}^{w}$ where $N_{t}^{w}$ is the number of those aged 20 and over. (5) If $\left\{T_{t}^{1}\right\}_{t=t_{1}}^{b+t_{1}}=\left\{T_{t}^{0}\right\}_{t=t_{1}}^{b+t_{1}}$ then stop, else update the guess for the sequence of transfers and repeat steps (1)-(5) until convergence. 


\section{References}

Auerbach, A.J. and Kotlikoff L.J. (1987), Dynamic Fiscal Policy. Cambridge University Press, New York.

Auerbach, A.J., Kotlikoff, L.J., Hagemann, R.P. and Nicoletti G.(1989), “The economic dynamics of an ageing population: the case of four OECD countries," OECD Economic Studies, 1989:97-130.

Auerbach, A.J. and Oreopoulos, Philip (1999), “Analyzing the Fiscal Impact of U.S. Immigration,” American Economic Review Papers and Proceedings, May, forthcoming.

Bogue, D.J. (1969), Principles of Demography. John Wiley and Sons, Inc. New York

Borjas, George J. (1994), “The Economics of Immigration,” Journal of Economic Literature 32: 16671717.

Bourbeau, R. and Legare, J. (1982), Evolution de la mortalite au Canada et au Quebec 1831-1931. Les Presses de l’Universite de Montreal, Canada.

Boyer, George R., Hatton, Timothy J., and O’Rourke, Kevin (1994), “The Impact of Emigration on Real Wages in Ireland, 1850-1914," in Migration and the International Labor Market, 1850-1939.

T.J. Hatton and J.G. Williamson, editors. Oxford University Press, New York.

Card, David (1997), “Immigrant Inflows, Natice Outflows, and the Local Labor Market Impacts of Higher Immigration.” National Bureau of Economic Research Working Paper No. 5927.

Coale, A.J. and Zelnik, M., (1963), New Estimates of Fertility and Population in the United States. Princeton University Press, Princeton.

Costa, D. (1998), The Evolution of Retirement, The University of Chicago Press, Chicago.

Field, F.W. (1914), Capital Investments in Canada, Third Edition. The Monetary Times of Canada, Toronto. 
Firestone, O.J. (1958), Canada's Economic Development, 1867-1956. Bowes \& Bowes, London. Filer, Randall K. (1992), “The Effect of Immigrant Arrivals on Migratory Patterns of Natives.” In Immigration and the Work Force. George J. Borjas and Richard B. Freeman, editors. The University of Chicago Press, Chicago.

Friedberg, Rachel, and Hunt, Jennifer (1995), “The Impact of Immigrants on Host Country Wages, Employment and Growth," Journal of Economic Perspectives 9(2): 23-44.

Green, A.G. (1994), "International Migration and the Evolution of Prairie Labor Markets in Canada, 1900-30," in Migration and the International Labor Market, 1850-1939. T.J. Hatton and J.G. Williamson, editors. Oxford University Press, New York.

Green, A.G. (1999), “Twentieth Century Canadian Economic History,” prepared for the Cambridge Economic History of the United States, forthcoming. S. Engerman and R. Gallman, editors.

Green, A.G. and MacKinnon, M. (1997), "Were the British Better? A Comparison of Immigrant and Native-Born Male Employees in Toronto, 1901," manuscript.

Green, A.G. and Sparks, G.R.(1999), "Population Growth and the Dynamics of Canadian Development: A Multivariate Time Series Approach,” Explorations in Economic History, 36: 56-71.

Green, A.G. and Urquhart, M.C. (1976), "Factor and Commodity Flows in the International Economy of 1870-1914: A Multi-Country View,” Journal of Economic History :217-252.

Hatton, T.J. and Williamson, J.G. (1994), “International Migration 1850-1939: An Economic Survey,” in Migration and the International Labor Market, 1850-1939. T.J. Hatton and J.G. Williamson, editors. Oxford University Press, New York.

Huggett, M. (1996), "Wealth distribution in life-cycle economies," Journal of Monetary Economics 38 : 469-494.

Hurd, M.D. (1989), “Mortality Risk and Bequests,” Econometrica 57, 4: 779-814. 
McInnis, R.M. (1994), "Immigration and Emigration: Canada in the Late Nineteenth Century," in Migration and the International Labor Market, 1850-1939. T.J. Hatton and J.G. Williamson, editors. Oxford University Press, New York.

McInnis, R.M. (1999a), “The Population of Canada in the Nineteenth Century," to appear in the Cambridge Population History of Noth America. M. Haines and R. Steckel, Editors.

McInnis, R.M. (1999b), “Canada's Population in the Twentieth Century,” to appear in the Cambridge Population History of Noth America. M. Haines and R. Steckel, Editors.

McLean, I. (1994), "Saving in Settler Economies: Australian and North American Comparisons," Explorations in Economic History 31: 432-452.

O’Rourke, Kevin, Williamson, Jeffrey G., and Hatton, Timothy J, (1994), "Mass Migration, Commodity Market Integration and Real Wage Convergence: The Late-Nineteenth-Century Atlantic Economy," in Migration and the International Labor Market, 1850-1939. T.J. Hatton and J.G. Williamson, editors. Oxford University Press, New York.

Parr, J. (1980), Labouring Children. McGill-Queen's University Press, Montreal.

Pope, David, and Withers, Glenn (1994), "Wage Effects of Immigration in Late-Nineteenth-Century Australia," in Migration and the International Labor Market, 1850-1939. T.J. Hatton and J.G. Williamson, editors. Oxford University Press, New York.

Ransom, R.L., and Sutch, R. (1986), “The Labor of Older Americans: Retirement of Men On and Off the Job, 1870-1937," Journal of Economic History 46: 1-30.

Rios-Rull, J.V. (1994), "Population Changes and Capital Accumulation: The Aging of the Baby Boom," manuscript, University of Pennsylvania.

Rios-Rull, J.V. (1997), “Computation of Equilibria in Heterogeneous Agent Models,” manuscript, University of Pennsylvania.

Simon, M. (1970), “New British Investment in Canada,” Canadian Journal of Economics, 3: 238-254. 
Storesletten, K. (2000), “Sustaining Fiscal Policy Through Immigration,” Journal of Political Economy 108: 300-323.

Taylor, A.M. (1997), "Peopling the Pampa: On the Impact of Mass Migration to the River Plate, 18701914," Explorations in Economic History 34:100-132.

Taylor, A.M. and Williamson, J.G. (1994), "Capital Flows to the New World as an Intergenerational Transfer," Journal of Political Economy 102: 348-371.

Troper, H.M. (1972), Only Farmers Need Apply. Griffin Press Limited, Toronto.

Urquhart, M.C. (1988), “Canadian Economic Growth 1870-1980,” Institute for Economic Research Discussion Paper No. 734, Queen's University at Kingston, Ontario, Canada.

Urquhart, M.C. (1993), Gross National Product, Canada 1870-1926: The Derivation of the Estimates. McGill-Queen's University Press, Kingston.

Urquhart, M.C. and Buckley, K.A.H. (1965), Historical Statistics of Canada. Cambridge University Press, Cambridge.

Williamson, J.G. (1998), "Growth, Distribution, and Demography: Some Lessons from History," Explorations in Economic History 35:241-271.

Wilson, S.J. (2000), “The Savings Rate Debate: Does the Dependency Hypothesis Hold for Australia and Canada?" Australian Economic History Review 40 (2): 199-218. 
Figure 1: Canadian Gross Domestic Capital Formation, Savings and Capital Inflow Rates, 18701914

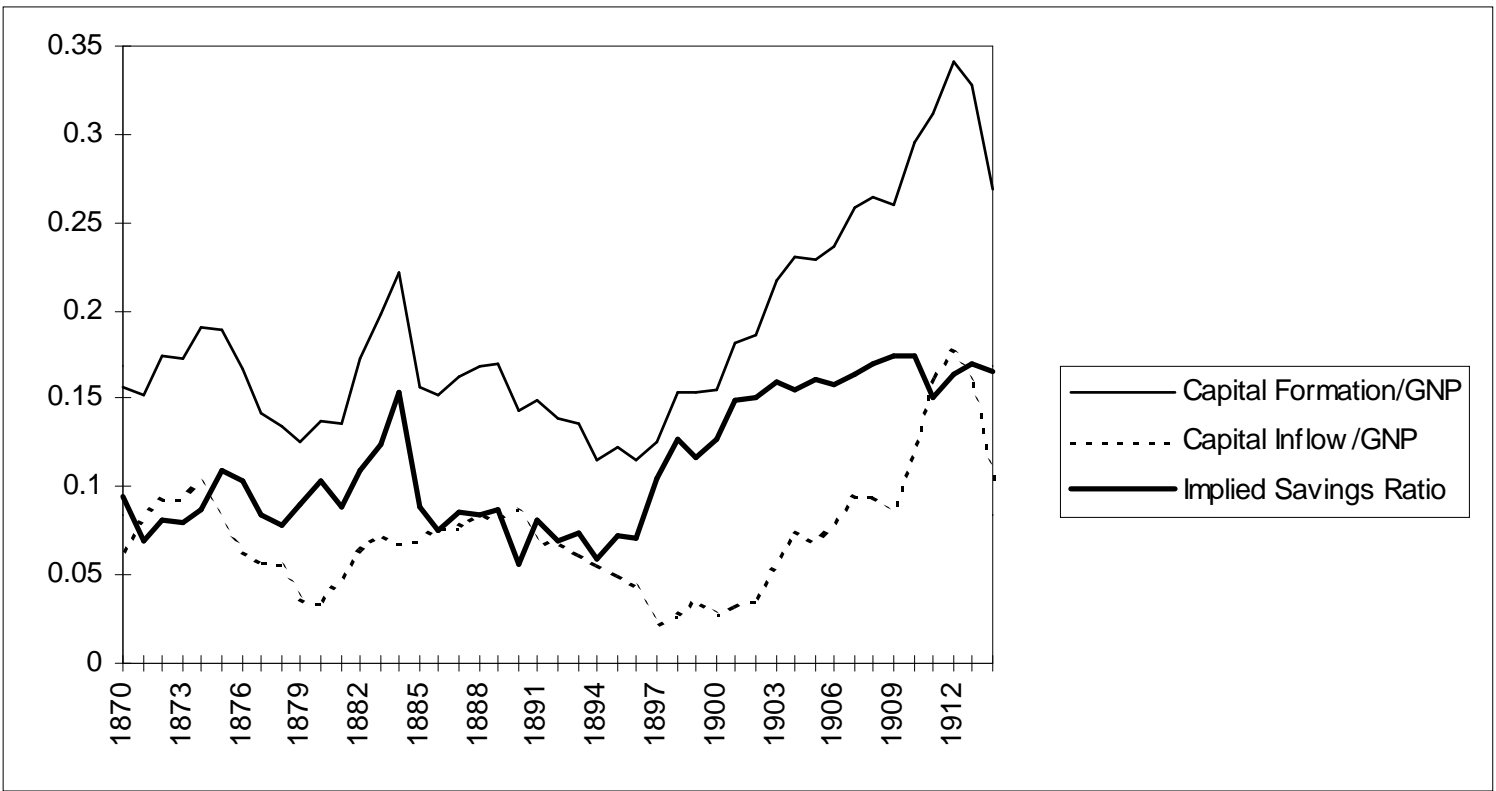

Source: Urquhart (1988). 
Figure 2: Migration in Canada, 1870-1914

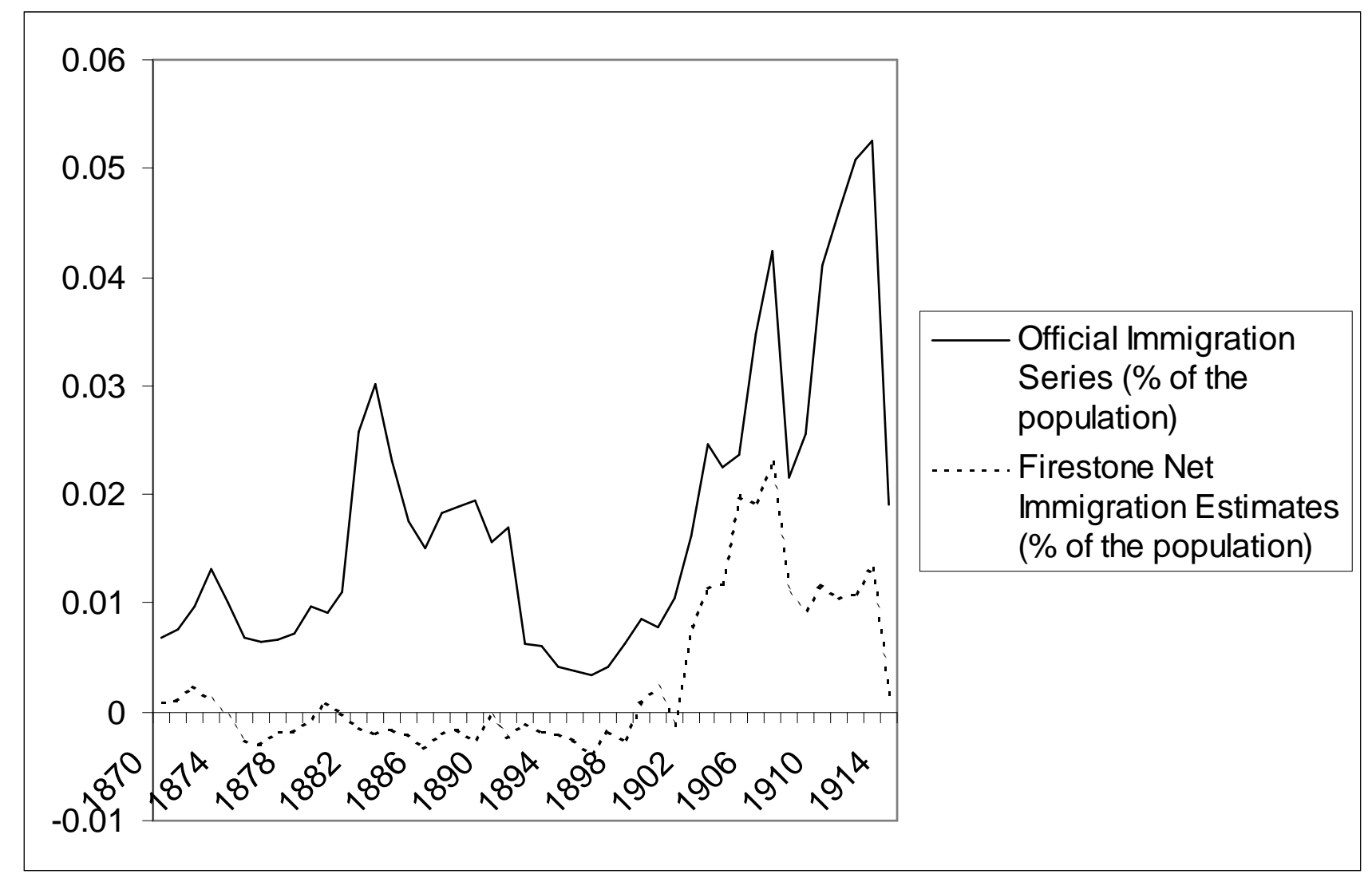

Sources: Urquhart and Buckley (1965), Firestone (1958). 
Figure 3: Age-Specific Migration Rate Parameters in the First Steady-State

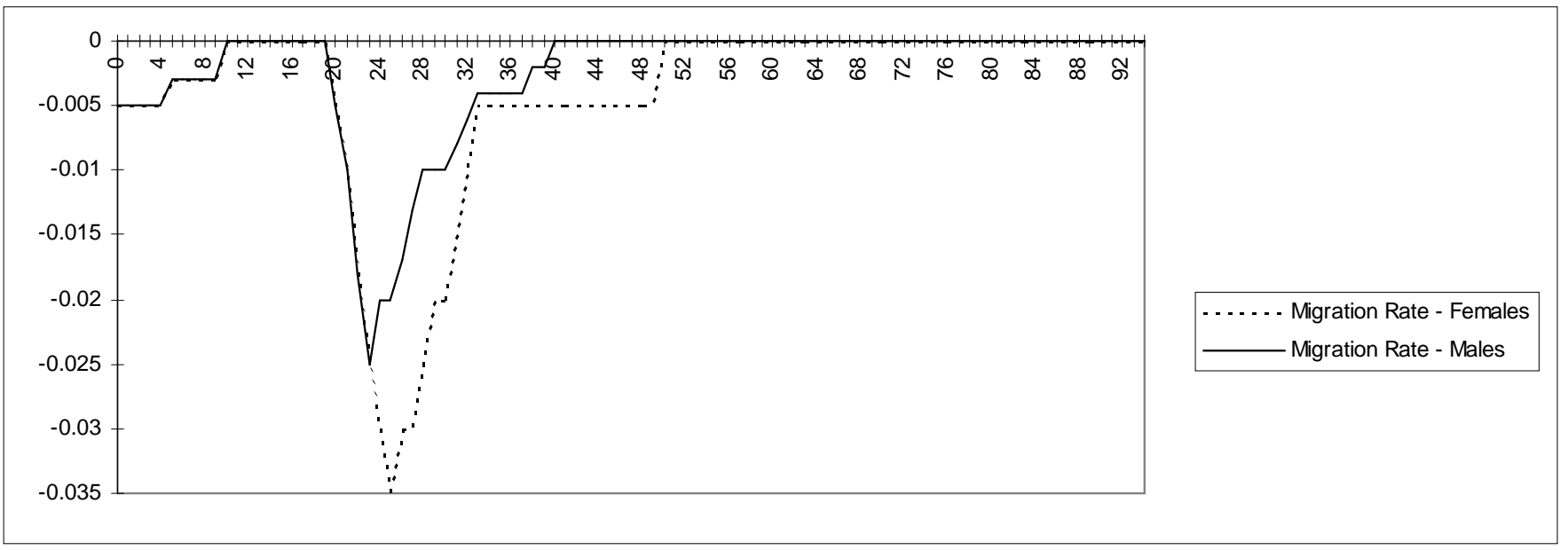

Figure 4: Age-Specific Migration Rate Parameters in the Second Steady-State

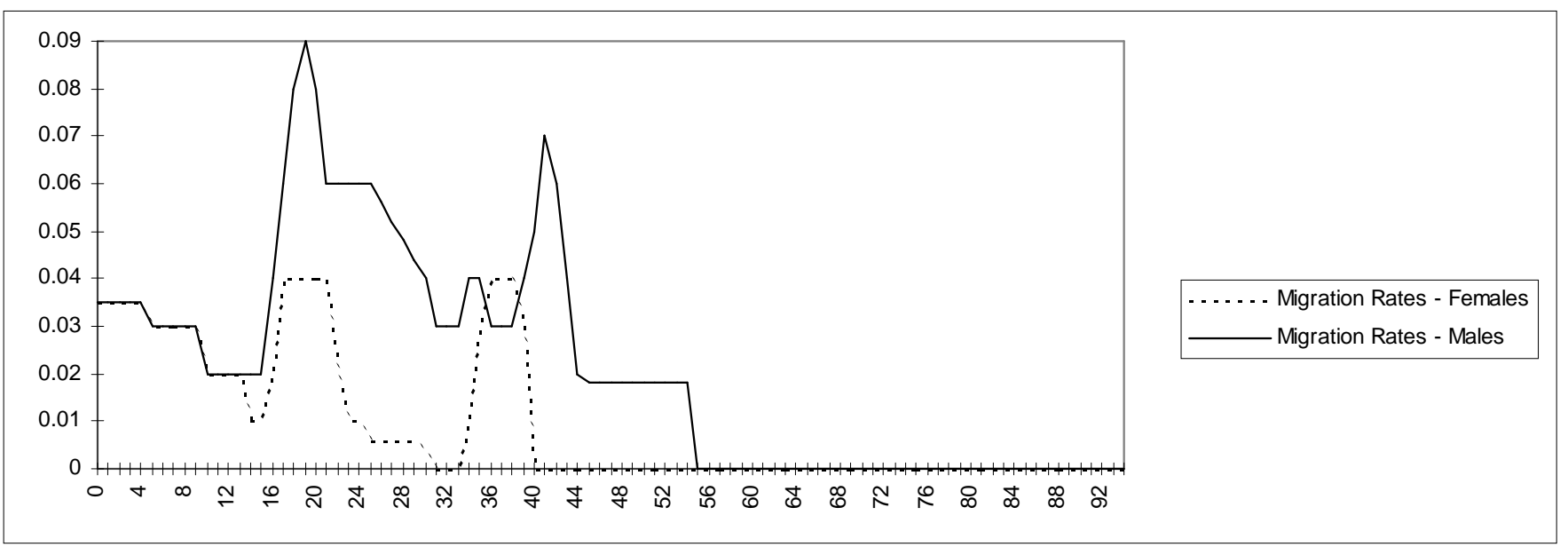


Figure 5: Age-Specific Labour Endowment Parameters

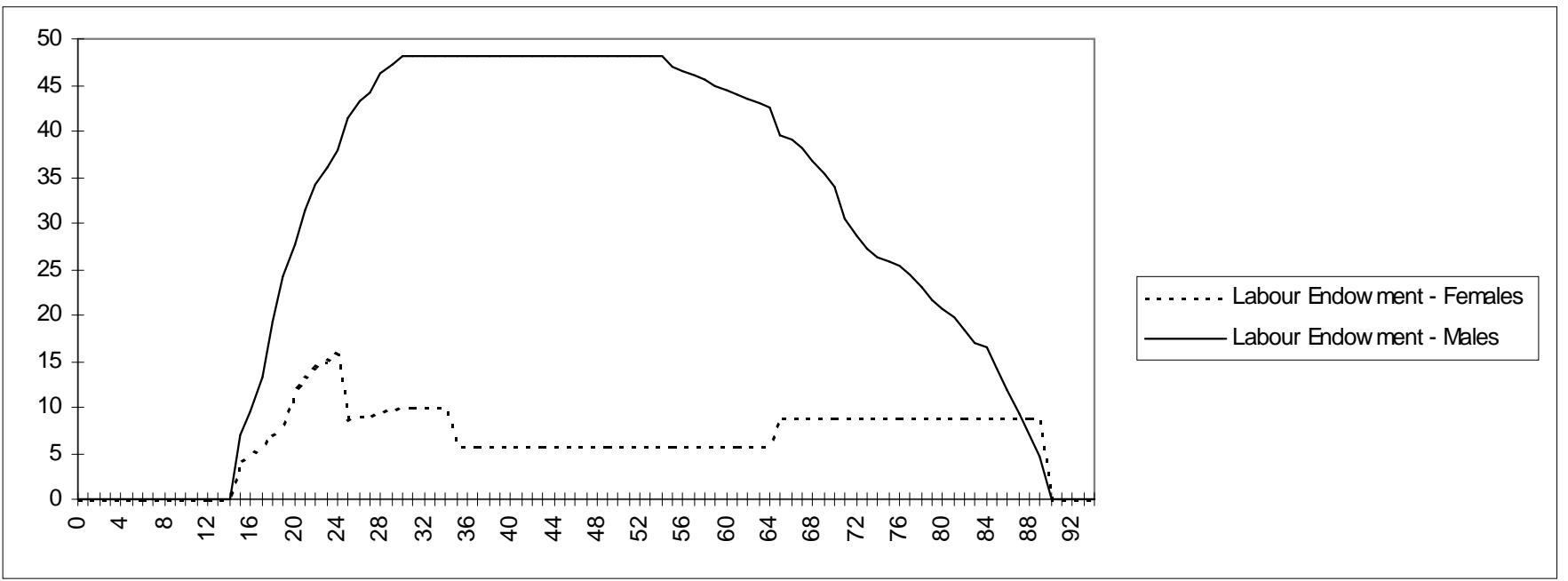

Figure 6: Migration in Canada, 1891-1914 - Comparison of Estimates and Model Economy

\section{Figures}

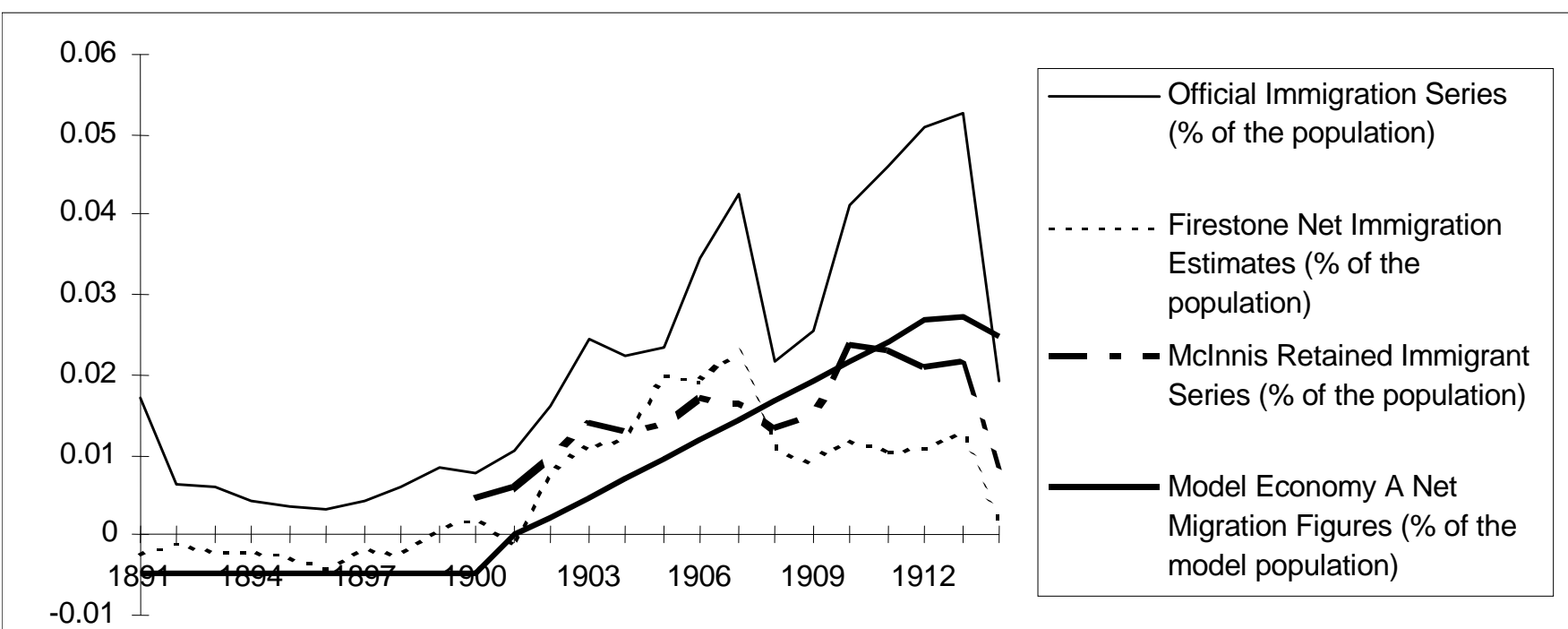


Figure 7: Model Economy Results - Gross Domestic Capital Formation, Domestic Savings and

\section{Foreign Capital Inflow Rates}

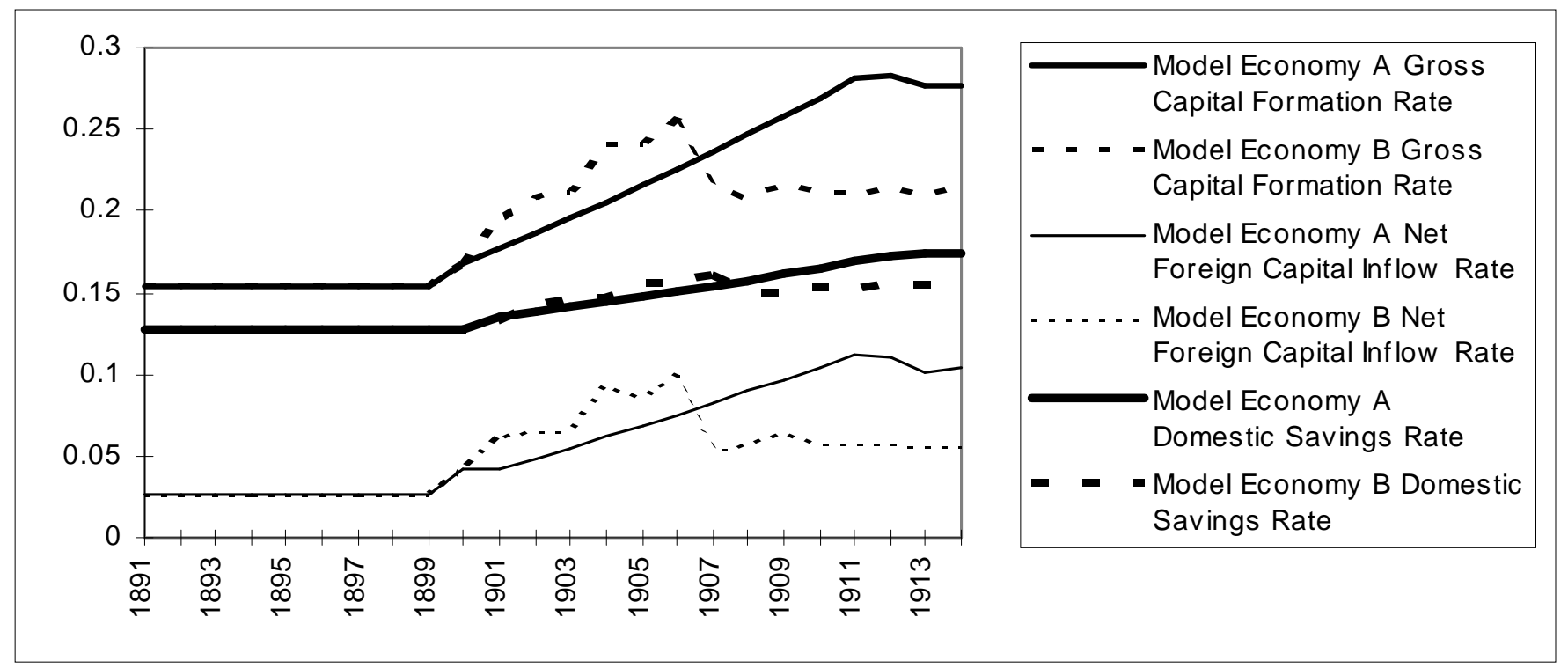

Figure 8: Comparison of Estimates and Model Economy Results - Gross Domestic Capital

\section{Formation Rates}

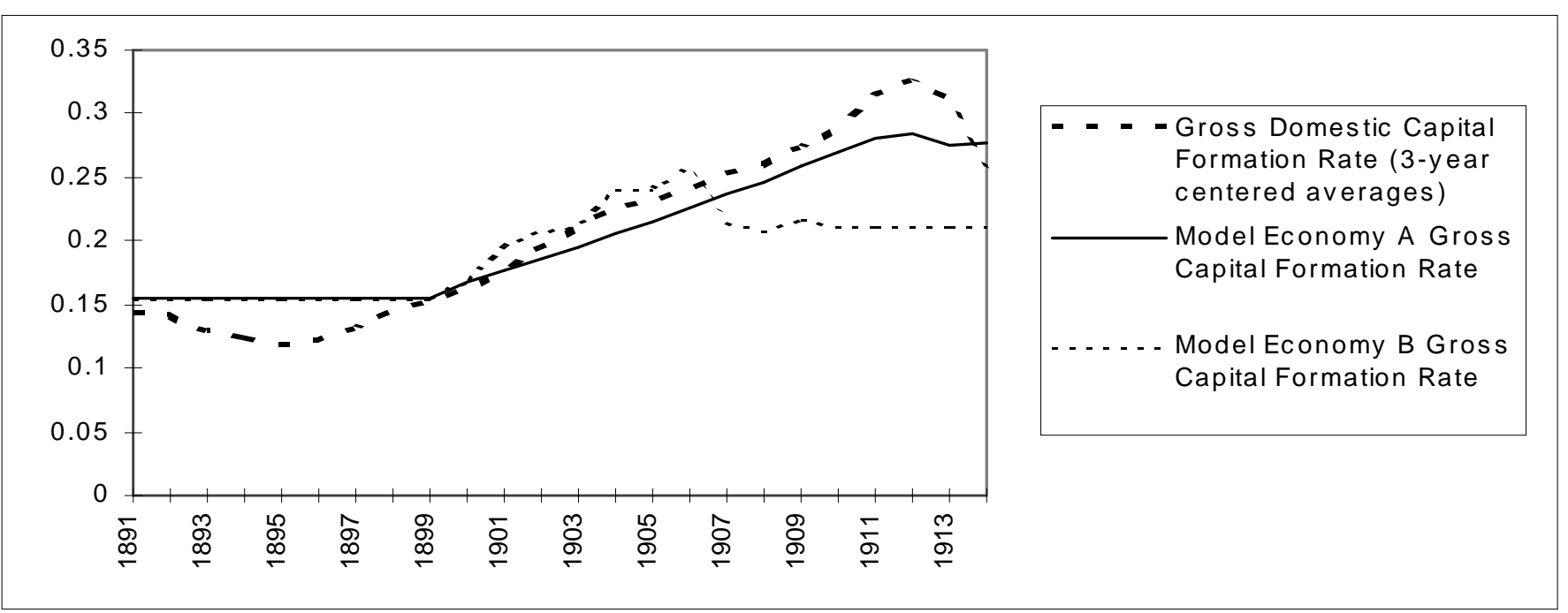


Figure 9: Comparison of Estimates and Model Economy Results - Domestic Savings Rates

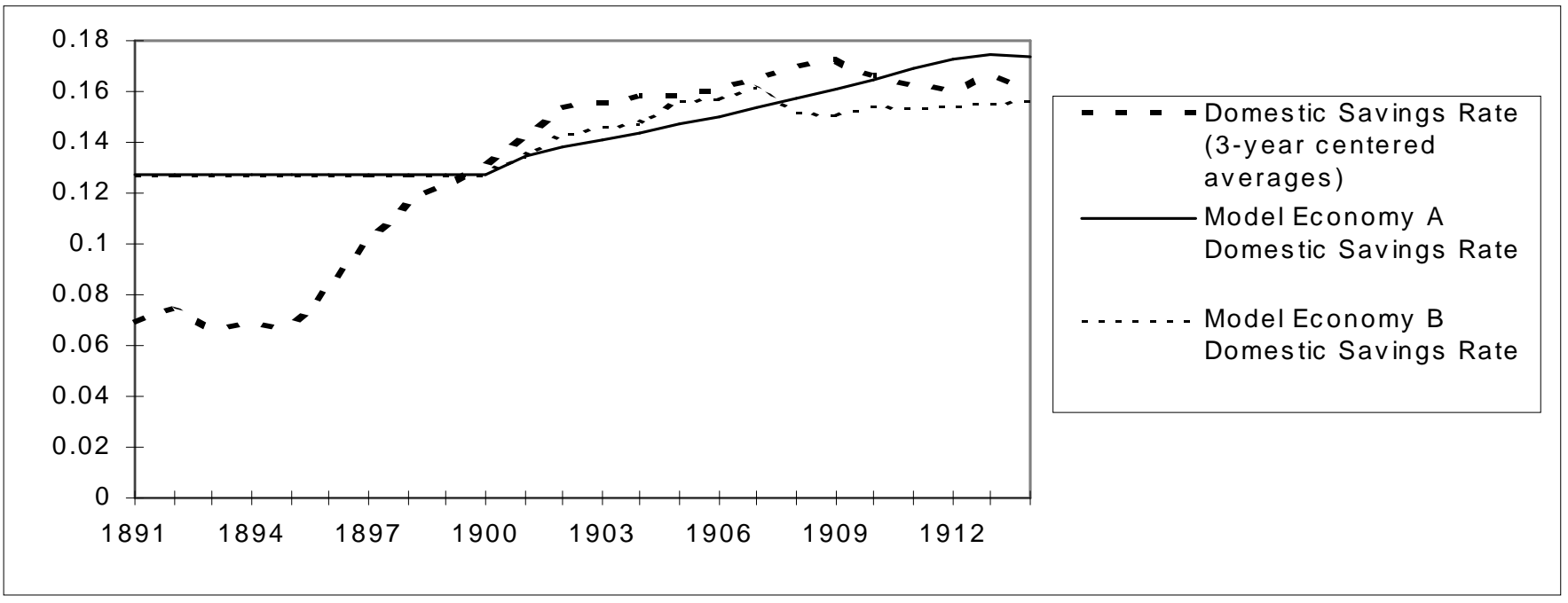

Figure 10: Comparison of Estimates and Model Economy Results - Foreign Capital Inflow Rates

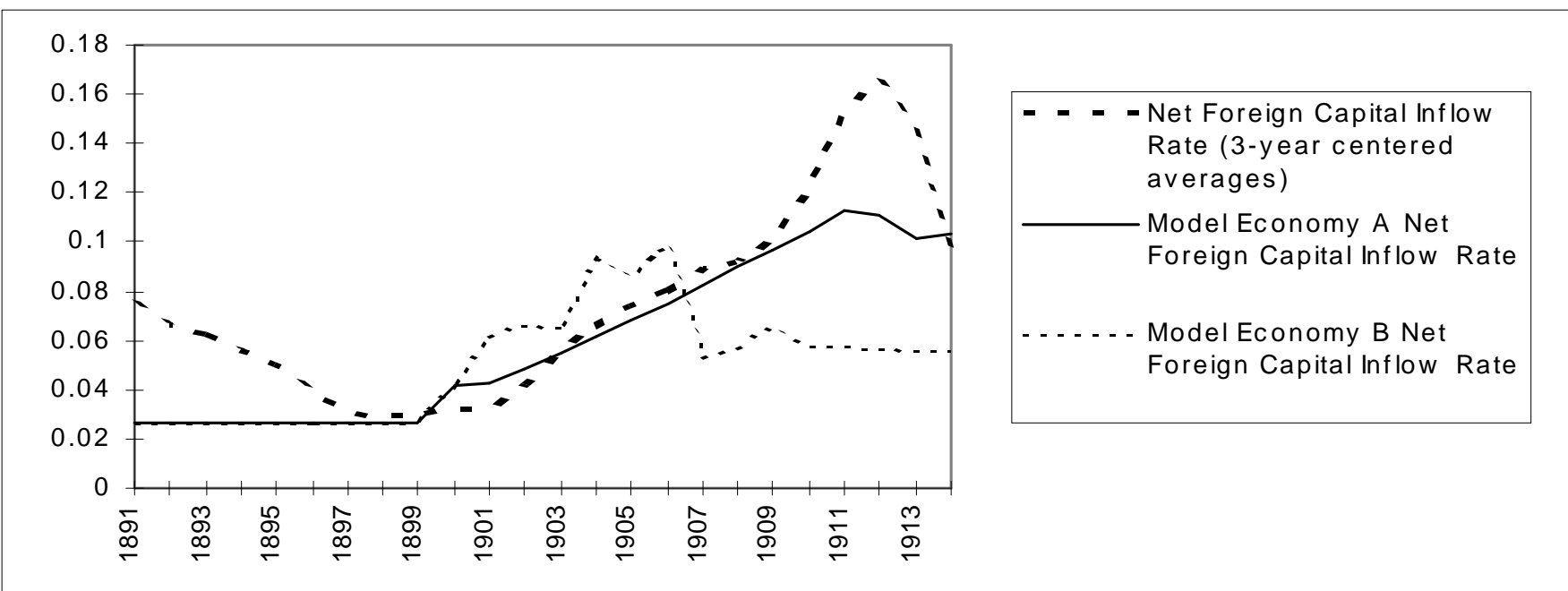


Table I: Steady-State Model Results

\begin{tabular}{lcc}
\hline Model Economy Results & Steady-State 1 & Steady-State 2 \\
\hline Population growth rate & $0.43 \%$ & $3.54 \%$ \\
Real national income growth rate & $2.28 \%$ & $5.39 \%$ \\
Real per capita national income growth rate & $1.85 \%$ & $1.85 \%$ \\
Gross domestic capital formation rate (as a & $15.4 \%$ & $27.2 \%$ \\
percentage of national income) & & \\
Gross domestic savings rate (as a percentage of & $12.7 \%$ & $16.9 \%$ \\
national income) & & \\
Foreign capital inflow rate (as a percentage of & $2.7 \%$ & $10.3 \%$ \\
national income) & & \\
Capital-output ratio & 2.5 & 2.5 \\
\hline
\end{tabular}

Table II: Comparison of Canadian Data and Model Economy Results

\begin{tabular}{lccc}
\hline Variable & $\begin{array}{c}\text { Change in the } \\
\text { Canadian Value } \\
\text { (three-year centered } \\
\text { average) } 1899 \text { to } \\
1911\end{array}$ & $\begin{array}{c}\text { Change in the } \\
\text { Model Economy } \\
\text { Value, 1899 to 1911 }\end{array}$ & $\begin{array}{c}\text { Proportion of the } \\
\text { Rise Explained by } \\
\text { the Change in } \\
\text { Migration }\end{array}$ \\
$\begin{array}{lccc}\text { Gross Domestic } \\
\begin{array}{l}\text { Capital Formation } \\
\text { Rate }\end{array} & 0.162 & \text { A: } 0.127 & \text { A: } 79 \% \\
\begin{array}{l}\text { Domestic Savings } \\
\text { Rate }\end{array} & \text { B: } 0.058 & \text { B: } 36 \% \\
\begin{array}{l}\text { Foreign Capital } \\
\text { Inflow Rate }\end{array} & 0.039 & \text { A: } 0.042 & \text { A: } 106 \% \\
\text { B: }: 69 \%\end{array}$ \\
\hline
\end{tabular}

Note: A indicates the result for Model Economy A, similarly, B indicates the result for Model Economy B. 


\section{Footnotes}

1 During the study period, most immigrants were from the British Empire or the United States, the two richest nations in the world at the time. Green and MacKinnon (1997, Figure 3) found that immigrants received wages comparable to those of natives in Toronto in 1901.

2 This is to simplify the analysis. The Canadian Government was active in building up social capital, funded by debt securities, land sales and trade duties. There were no personal income taxes during the period of study.

3 Accidental bequests have been treated several different ways. Storesletten (2000) has accidental bequests donated to newborns in a lump sum transfer. Rios-Rull (1994) introduces a market that has agents write contracts with members of their own age cohort to share wealth or debts of those members who die before age $I$. The model developed by Huggett (1996) treats accidental bequests as fully taxed and redistributed amongst surviving agents. The treatment here follows Huggett.

4 The method for calculating the steady-state population distributions and stationary equilibria is described in the appendix.

5 A more detailed description is included in the appendix.

6 The retirement age is set to 90 arbitrarily. The life-cycle motive of savings will be captured by the decline in employment rates for males over 65 years of age (this decline will be described later).

7 The sex ratio of births in the United States over 1940-1965 was consistent at 1.05:1 (Bogue (1969)).

${ }^{8}$ This procedure introduces a bias in the estimates. Under-enumeration of the young and elderly is generally present, so that ten year estimates do not regularly conform to the next census' figures. As such, I concentrated on the cohort groups over the ages of 15 to 55. While it is assumed that those over age 50 generally do not migrate, emigration rates of those older than 55 were set to zero. The resulting emigration rate estimates appear to be quite low for children, if we assume that families were migrating. 
Even with rates set to zero in the model, the census figures imply that children are immigrating, or are under-enumerated. During this period, the British Empire was sending children to the New World to integrate into new families. 80,000 British children were sent to Canada between 1868 and 1925 as labourers, unaccompanied by parents (Parr (1980: 11)).

${ }^{9}$ A comparison between the actual census figures and the results of modeling the population for ten years up to the census date are available as an appendix upon request from the author.

${ }^{10}$ US families were able to take free homestead lands, and purchase neighboring school lands, railway lands, or Hudson's Bay Company lands. Canadian immigrant agents actively courted US families who couldn't afford to buy neighboring farms in the US for their sons (Troper (1972:40-41)).

${ }^{11}$ Ransom and Sutch (1986) report that the average wage of Michigan furniture workers aged 55 and older was 0.94 times that of workers aged 20 to 54 .

${ }^{12}$ Wage estimates in Urquhart and Buckley (1965) at the beginning of the century indicate females earned approximately half the wages of men (for example hourly rates of female spinners and monthly rates of domestic workers were about half those of male loom fixers and lumbermen respectively). ${ }^{13}$ Costa (1998: Fig. 2.5) reports employment rates for men up to the age of 85 . The employment rates of men were set to decline steadily from the age of 85 to "full" retirement at age 90.

${ }^{14}$ The capital output ratio generated by the model with the parameters specified above is 2.5 . Urquhart (1988) estimates a capital-output ratio (excluding residential capital) ranging from 2.5 to 3.9 in 1971 dollars from 1926 to 1983 , excluding the depression of the 1930s.

15 The transition in the economy was computed over a thousand periods, however, the model economy converges well before this time horizon. After 70 periods, the difference between the value of accidental bequests and the value of accidental bequests in the second steady-state is less than one percent of the second steady-state value. 
${ }^{16}$ Immigrant funds were recorded as current receipts in the current account, not as a foreign capital inflow.

17 More than $80 \%$ of British money calls over 1865-1914 consisted of social overhead capital, government or government guaranteed debt (Simon (1970: 242)).

18 The capital-labour ratio is constant in the open-economy model with a constant rate of return to capital, so that the growth rate of output per worker is equal to the growth rate of $A$, denoting technological progress. 